\title{
Daring to build fair and sustainable urban food systems: A case study of alternative food networks in Australia
}

\begin{abstract}
Urban food systems are under pressure from climate change, resource scarcity and increasing urbanization and so are in need of significant transformation. Alternative food networks are initiatives that are part of urban food systems and have goals of improving environmental stewardship and social justice. The features of alternative food networks can be linked to the outcomes expected of sustainable and resilient urban food systems. This paper presents a case study of alternative food networks operating in Brisbane and Melbourne in order to analyze: i) their socio-economic and environmental contributions to the resilience and sustainability of urban food systems; and, ii) the limitations that alternative food networks face in expanding their operations. The initiatives that were part of the study include urban agriculture promoters, food hubs, buyers' groups, and specialist retailers. The results indicate that alternative food networks can improve access to healthy food, provide fairer conditions for farmers, reduce food loss/waste, increase environmental protection, and facilitate climate change adaptation. The main limitations to the expansion of alternative food networks include the restricted access to land for growing food, low public engagement, and the dependence on volunteer labor. This paper concludes by summarizing the contribution of alternative food networks to urban food systems and identifies directions for future research.
\end{abstract}

Key words: new localism; food security; urban farming; food sovereignty; climate action.

\section{Introduction}

The Australian food system is often environmentally damaging and vulnerable to the impacts of climate change (Lawrence et al., 2013; Burton et al., 2013). Climate change is likely to increase the risk of the Australian food system to water scarcity, drought, heatwaves, bushfires, and extreme weather events such as floods and storms across the country (Burton et al., 2013). The vulnerability of the Australian food system to these impacts is exacerbated by the centralization of supply chains and a limited range of food outlets (Lawrence et al., 2013) - a situation that also impacts on 
food access. Australia produces more than enough food to feed its population (Hughes et al., 2015), however, 17\% of people living in urban areas in 2018 experienced food insecurity due to unaffordability (Food Bank, 2018). All of this suggests that an urgent transformation is needed to make the Australian food system sustainable and resilient in light of the growing impacts of climate change.

Some Australian local governments have started to develop urban food system (UFS) policies that strive for sustainability by reconciling health, environmental and socio-economic factors (Dixon and Richards, 2016; Sonnino et al., 2018). The goals of such policies, and the aspects required for resilient UFS, seem concordant with alternative food networks (AFNs) that embody the values of social justice, environmental sustainability, community health, and democracy (Levkoe, 2011; Matacena, 2016). AFNs have emerged over the last decades as a bottom-up social phenomenon (Barbera and Dagnes, 2016; Berti and Mulligan, 2016) and consist of food provisioning initiatives that seek to operate outside the industrial globalized supply chains (Forssell and Lankoski, 2016). Farmers' markets are the most traditional form of AFNs, but more innovative models have started to spread, such as food hubs and buyers' groups.

Previous studies have identified the positive social and environmental outcomes of AFNs worldwide (Fonte, 2013; Lutz and Schachinger, 2013; Saulters et al., 2018), however, a more detailed investigation of how these link to the sustainability and resilience of UFS is still needed. In particular, there are only a few studies focusing on the Australian context. AFNs are a small player in the Australian food system, but they seek to challenge the accountability of dominant supply chains in terms of reducing negative social and environmental impacts and building local community capacity. This paper uses a framework centered on the concepts of sustainability and resilience to investigate how new and innovative AFNs from Brisbane and the Melbourne metropolitan region are influencing UFS. Specifically, the paper provides an investigation of AFNs' contribution to the socio-economic aspects of healthy food access and connectivity between urban and rural areas. It also discusses how AFNs contribute to better environmental performance by adopting efficient resource supply chains that reduce intermediaries and relate to the local natural environment.

The following section presents the conceptual framework that guided the data collection and analysis. The paper then describes how the case studies were carried out in Brisbane and the Melbourne metropolitan region. The results discuss the distinct 
contributions of AFNs to socio-economic and environmental outcomes as well as the limitations that they face with regards to expansion. The paper concludes with a summary of the contribution of AFNs to UFS and how these initiatives can be broadened, along with suggestions for future research.

\section{Conceptual Framework: Socio-economic and environmental outcomes of sustainable and resilient UFS}

The conceptual framework guiding this study was derived from a literature review that investigated key socio-economic and environmental outcomes related to sustainable and resilient UFS. This literature indicates that a sustainable UFS is one that has an economy that serves social needs while safely operating within the environmental limits of the Earth's systems (Giddings et al., 2002; Rockström et al. 2009). The impacts of climate change, however, require that UFS also be resilient. This means that UFS should be able to deal with, and recover from, extreme weather events, as well as adapt and ultimately transform themselves in response to the ongoing impacts of a changing climate (Folke, 2016).

Often the sustainability and resilience outcomes of UFS are discussed separately, with sustainability being more frequently covered in the literature (Sonnino and Spayde, 2014; Vieira et al., 2018). There is the potential to integrate sustainable and resilient outcomes because they deal with similar socio-economic and environmental aspects of UFS. Different emphases are used when resilience is applied to UFS (e.g. analyses tend to focus on features like diversity of food production systems and food supply networks), but these differences do not compete with sustainability goals (Vieira et al., 2018).

A range of socio-economic and environmental outcomes have been identified in the literature concerning sustainable and resilient UFS, such as: the adoption of fair trade (Hinrichs, 2010; Sonnino, 2016), the generation and transfer of food knowledge and skills (Anderson, 2015; Calori et al., 2017), and the use of participative decisionmaking processes (Desmarais and Wittman, 2014; Morgan, 2015; Moragues-Faus, 2016). While all these outcomes are also relevant to UFS sustainability and resilience, this paper specifically focuses on socio-economic outcomes related to healthy food access in urban areas, and the creation of urban-rural connections, along with environmental outcomes centered on reducing food waste, and improving 
environmental protection. Table 1 expands on the outcomes guiding principles and references to other studies. While the outcomes were not derived from the AFNs literature in specific, they are applicable to AFNs because these are part of UFS.

Table 1: Conceptual Framework: key socio-economic and environmental outcomes of sustainable and resilient UFS.

\begin{tabular}{|c|c|c|c|}
\hline \multicolumn{2}{|c|}{ Key Outcomes } & Guiding Principles & Sources \\
\hline \multirow{2}{*}{ 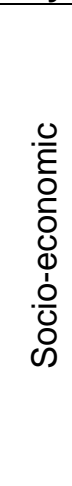 } & $\begin{array}{l}\text { Healthy food } \\
\text { access }\end{array}$ & $\begin{array}{l}\text { People from all socio-economic } \\
\text { conditions should have access to } \\
\text { nutritional and healthy food in } \\
\text { order to address both malnutrition } \\
\text { and obesity. }\end{array}$ & $\begin{array}{l}\text { Blay-Palmer et al., 2015; Desmarais } \\
\text { and Wittman, 2014; Donovan et al., } \\
\text { 2011; Garnett, 2014; Hamm and } \\
\text { Baron, 1999; James and Friel, 2015; } \\
\text { Jennings et al., 2015; Moragues- } \\
\text { Faus and Morgan, 2015; Morgan, } \\
2015 .\end{array}$ \\
\hline & $\begin{array}{l}\text { Connectivity } \\
\text { between rural } \\
\text { and urban } \\
\text { areas }\end{array}$ & $\begin{array}{l}\text { A connection that allows an equal } \\
\text { flow of resources and/or } \\
\text { information between urban and } \\
\text { rural areas should be promoted. }\end{array}$ & $\begin{array}{l}\text { Anderson, 2015; Billen et al., 2012; } \\
\text { Cretella and Buenger, 2016; Custot } \\
\text { et al., 2012; Jennings et al., 2015; } \\
\text { Morgan and Sonnino, 2010; RUAF, } \\
2013 \text {. }\end{array}$ \\
\hline \multirow[b]{2}{*}{ 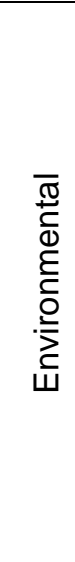 } & $\begin{array}{l}\text { Food loss and } \\
\text { waste } \\
\text { reduction }\end{array}$ & $\begin{array}{l}\text { There should be a reduction in } \\
\text { food loss and waste as well as the } \\
\text { promotion of nutrient recycling } \\
\text { practices. }\end{array}$ & $\begin{array}{l}\text { Bristol City Council, 2013; Carey, } \\
\text { 2013; Hanson and Schrader, 2014; } \\
\text { Moragues-Faus et al., 2016; } \\
\text { Wiskerke, } 2015 .\end{array}$ \\
\hline & $\begin{array}{l}\text { Environmental } \\
\text { protection }\end{array}$ & $\begin{array}{l}\text { UFS need to be decoupled from } \\
\text { fossil fuels to act on climate } \\
\text { change mitigation. In order to } \\
\text { adapt to the impacts of climate } \\
\text { change, UFS should maintain } \\
\text { ecosystem services, regenerate } \\
\text { natural resources, and restore } \\
\text { biodiversity. This includes a } \\
\text { reduction in the use of herbicides, } \\
\text { pesticides and artificial fertilizers. }\end{array}$ & $\begin{array}{l}\text { Calori et al., 2017; Hanson and } \\
\text { Schrader, 2014; James and Friel, } \\
\text { 2015; Moragues-Faus and Morgan, } \\
\text { 2015; Sonnino and Spayde, } 2014 .\end{array}$ \\
\hline
\end{tabular}

\section{Methods}

This research adopted a comparative case study approach (Patton, 2015; Yin, 2009) with the goal of analyzing the contributions of AFNs to the sustainability and resilience of two UFS in Australia. The two case study areas consisted of the City of Brisbane and four local governments in the Melbourne metropolitan region (Figure 1) ${ }^{1}$. Both areas have similar levels of economic development but significant differences in UFS policies. All four local governments in the Melbourne metropolitan region have food policies/strategies (City of Darebin, 2014; Melbourne Council, 2012; Moreland

\footnotetext{
${ }^{1}$ Local governments in Australia vary in size and associated jurisdictions. The local government area of Brisbane is one of the largest urban authorities in the country (approximately 1,300 $\mathrm{km}^{2}$ ), while the Melbourne metropolitan region comprises 31 local authorities.
} 
City Council, 2017; Yarra City Council, 2014), while the City of Brisbane has no food policies or strategies in place.

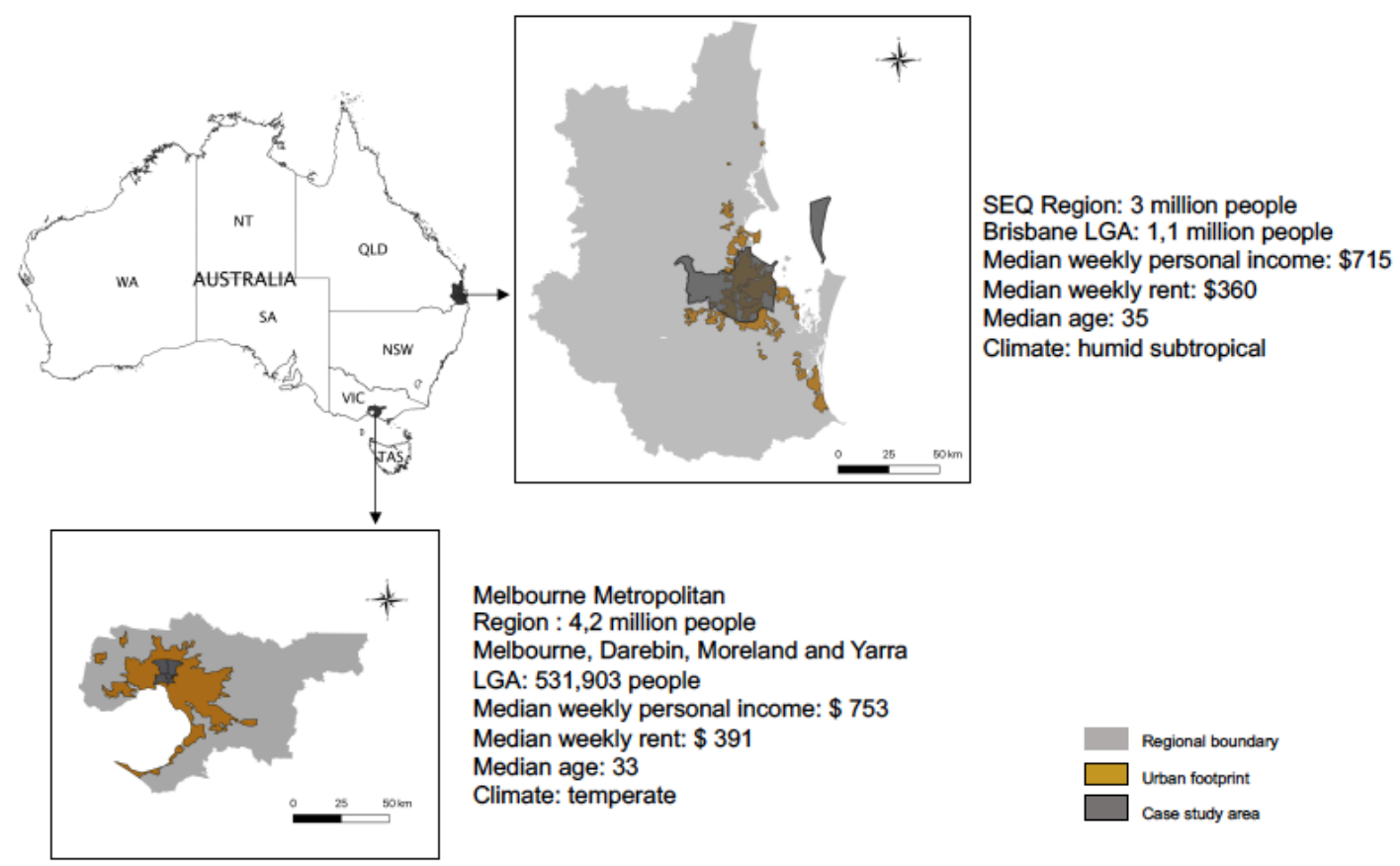

Figure 1: Case study areas - Brisbane City and Melbourne Metropolitan Region (Data source: $A B S, 2016)$.

\subsection{Selection of initiatives}

The sampling strategy adopted was based on what Patton (2015) describes as 'maximum variation' in order to gather a diverse picture of AFNs. Australian Farmers' markets and community gardens were not the primary type of initiatives included in this research because they have already been the focus of other studies (e.g. Guitart et al., 2015; Thornton, 2017). Instead, this research aimed to include a variety of initiatives to enable a comparison of cases that were selected based on the primary goals of increasing public access to healthy food, securing fairer conditions for food workers, sharing knowledge about food growing, and reducing environmental impacts. AFNs were identified using publicly available information. Sixteen were contacted by the authors and nine agreed to participate in this study. These were grouped into four clusters that are described in Table 2. 
Table 2: Description of the initiatives that participated in the study.

\begin{tabular}{|c|c|c|c|c|}
\hline Type & Initiatives' operational structure & Initiatives' goals & Motivation behind their creation & $\begin{array}{l}\text { Number of initiatives by location } \\
\text { and interviewees' pseudonyms }\end{array}$ \\
\hline $\begin{array}{l}\text { Urban } \\
\text { Agriculture } \\
\text { Promoters }\end{array}$ & $\begin{array}{l}\text { These are initiatives that seek to facilitate the } \\
\text { establishment of public and private gardens } \\
\text { and disseminate knowledge on food growing. } \\
\text { Two of the initiatives operate in a not-for-profit } \\
\text { charity structure and one is collectively run by } \\
\text { volunteers. }\end{array}$ & $\begin{array}{l}\text { Increase knowledge on } \\
\text { food growing, increase } \\
\text { fresh food access, and } \\
\text { help to facilitate public } \\
\text { and private urban } \\
\text { gardens. }\end{array}$ & $\begin{array}{l}\text { Local residents who wanted to have } \\
\text { the opportunity to grow their own food } \\
\text { and share it with others. }\end{array}$ & $\begin{array}{l}\text { Brisbane (1): BUA1. } \\
\text { Melbourne (2): MUA1, MUA2 and } \\
\text { MUA3. }\end{array}$ \\
\hline $\begin{array}{l}\text { Buyers' } \\
\text { Group }\end{array}$ & $\begin{array}{l}\text { These are cooperatives of people who live in } \\
\text { the same neighborhood and use their } \\
\text { collective purchasing power to buy food } \\
\text { directly from producers or specialist retailers. } \\
\text { They are operated by volunteers and the roles } \\
\text { of members are rotated. }\end{array}$ & $\begin{array}{l}\text { Make locally-sourced, } \\
\text { healthy, fairer and } \\
\text { affordable food available; } \\
\text { seek to build community } \\
\text { spirit. }\end{array}$ & $\begin{array}{l}\text { One initiative was created by former } \\
\text { members of a buyers' group who } \\
\text { wanted one in their own } \\
\text { neighborhood. The other one started } \\
\text { as a university project and ended up } \\
\text { being adopted by the local } \\
\text { community. }\end{array}$ & $\begin{array}{l}\text { Brisbane (1): BBG1 and BBG2. } \\
\text { Melbourne (1): MBG1, MBG2, MBG3, } \\
\text { and MBG4. }\end{array}$ \\
\hline $\begin{array}{l}\text { Specialist } \\
\text { Retailer }\end{array}$ & $\begin{array}{l}\text { These are food retailers run by not-for-profit } \\
\text { social enterprises. One consists of a low-cost } \\
\text { fresh food market with a focus on food security } \\
\text { without having a high concern about ethical } \\
\text { supply chains or environmental impacts. The } \\
\text { second one is a wholesaler committed to } \\
\text { distributing food that is ethical, healthy, } \\
\text { environmentally sustainable, and affordable. }\end{array}$ & $\begin{array}{l}\text { Increase the access of } \\
\text { quality and healthy food } \\
\text { to all citizens. }\end{array}$ & $\begin{array}{l}\text { One initiative was founded by two } \\
\text { local residents worried about food } \\
\text { insecurity in urban areas. The other } \\
\text { started from the vision of the founder } \\
\text { who saw a gap in the local market. }\end{array}$ & $\begin{array}{l}\text { Brisbane (1): BSR1, BSR2 and BSR3. } \\
\text { Melbourne (1): MSR1 and MSR2. }\end{array}$ \\
\hline Food Hub & $\begin{array}{l}\text { These are social enterprises that are inspired } \\
\text { by the community supported agriculture } \\
\text { model. Produce is purchased from local } \\
\text { farmers that are payed a higher income. Local } \\
\text { consumers have to choose from a range of } \\
\text { products that are available or receive a ready- } \\
\text { made box. They only sell seasonal produce } \\
\text { that is grown using environmentally sound } \\
\text { practices. }\end{array}$ & $\begin{array}{l}\text { Enable a more } \\
\text { democratic and fair food } \\
\text { supply. }\end{array}$ & $\begin{array}{l}\text { One initiative started as a food co-op } \\
\text { and grew into a food hub. The other } \\
\text { originated from the founder's wish to } \\
\text { create a model based on community } \\
\text { supported agriculture for urban areas. }\end{array}$ & $\begin{array}{l}\text { Brisbane (1): BFH1, BFH2, BFH3, } \\
\text { BFH4, BFH5, BFH6 and BFH7. } \\
\text { Melbourne (1): MFH1. }\end{array}$ \\
\hline
\end{tabular}




\subsection{Data collection and analysis}

The data collection and analysis were guided by the conceptual framework presented in Section 2. Twenty-three semi-structured interviews were conducted with founders or members of AFNs between July and October 2018 (13 in Brisbane and 10 in Melbourne). The interviews aimed to collect information about: i) the process of operation of each initiative; ii) the AFNs' contribution to socio-economic and environmental outcomes; and, iii) the limits to the AFNs' operations and expansion. The semi-structured interviews were audio recorded and transcribed verbatim. The interviews were analyzed using a thematic content analysis following procedures described by Byrne (2016) and with help of the software NVivo 11 (QRS, 2017). The coding system was based on the outcomes presented in the conceptual framework (see Table 3). Information from AFNs' websites and social media was also used. Publicly available AFNs' online systems for orders were also accessed. Visits were conducted in the cases where the AFNs had a site or physical place of operation. This allowed for a more comprehensive picture of the functioning and extent of these initiatives, as well as the triangulation of data from different sources with observations and the literature.

Table 3: Coding system adopted in the data analysis.

\begin{tabular}{|l|l|}
\hline Node & Description \\
\hline Establishment & $\begin{array}{l}\text { Who started, when, and what resources, structures, and conditions } \\
\text { were involved in the AFN establishment. }\end{array}$ \\
\hline Operations & How the AFN works. \\
\hline Limitation & $\begin{array}{l}\text { Aspects that the AFN identify as a limitation (e.g. consumers } \\
\text { expectations, reliance on volunteers, resources). }\end{array}$ \\
\hline Healthy food access & $\begin{array}{l}\text { Types of products available, socio-economic characteristics of } \\
\text { members, food price, purchasing channels, and quality of the produce } \\
\text { (farming techniques, variety). }\end{array}$ \\
\hline Connectivity urban/rural & $\begin{array}{l}\text { Aspects that demonstrate positive exchanges and relationships } \\
\text { between urban and rural areas. }\end{array}$ \\
\hline Food loss and waste & Practices adopted that can contribute to reducing food loss and waste. \\
\hline Reduction of GHG emissions & Practices adopted that can contribute to reducing GHG emissions. \\
\hline Protection of ecosystems & $\begin{array}{l}\text { Environmentally friendly production practices or techniques associated } \\
\text { with the initiative use. }\end{array}$ \\
\hline
\end{tabular}

\section{Results and discussion}

The data analysis suggested that there are some common features of Australian AFNs. In particular, all interviewees had a tertiary education and a good understanding 
of food system issues. Only one of the AFNs was founded by a former farmer, in the other cases the founders were not previously involved with food production. The core values that interviewees attributed to their AFNs included environmental sustainability, community building, and the desire to improve UFS. All the participating initiatives had local food supply as the basis for their structure, which is consistent with AFNs internationally (Forssell and Lankoski, 2015). In the Australian context, however, local might not necessarily entail low food miles, although the urban agriculture initiatives did involve shorter travelling distances. The interpretation of local by AFNs resembles what Sonnino (2017) calls as the 'new localism'. This is where 'local' is considered to be something beyond geographical proximity and focuses more on the connection of food system actors, practices and knowledge (Sonnino, 2017). The main outcomes sought by AFNs with local food supply were closer relationships, accountability, and transparency. In this context, the concept of local food supply in Australia is used more as a means to achieve the socio-economic and environmental outcomes desired by members of AFNs.

\subsection{Socio-economic outcomes}

Table 4 presents a summary of how AFNs contributed to socio-economic outcomes of sustainable and resilient UFS. All the different types of AFNs contributed to the both socio-economic outcomes but differed in relation to access to healthy food. 
Table 4: Links between AFNs and socio-economic outcomes of sustainable and resilient UFS.

\begin{tabular}{|c|c|c|}
\hline 을 을 & 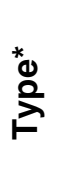 & Contributions \\
\hline \multirow{4}{*}{ 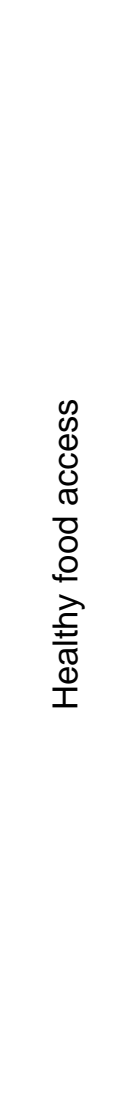 } & 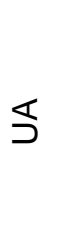 & $\begin{array}{l}\text { - People can grow some of their food. } \\
\text { Example: "It is clear that people grow a very deal of satisfaction from eating a } \\
\text { tomato that they grew [...]. I don't want to use the word empowering, but certainly } \\
\text { just makes them feel like they've got a bit more control over their inputs, their food." } \\
\text { (MUA3) }\end{array}$ \\
\hline & $\underset{\infty}{\text { ৩ }}$ & $\begin{array}{l}\text { - Organic food becomes more affordable. } \\
\text { Example: "You know what? } 30 \text { dollars, it is amazing when you put the value for } \\
\text { money, what you get inside of a box." (MBG3) }\end{array}$ \\
\hline & $\frac{\alpha}{\omega}$ & $\begin{array}{l}\text { - Buying in bulk can lower food prices. } \\
\text { Example: "If you get a group of people together and buy, we will sell to you at } \\
\text { wholesale prices" (BSR2) } \\
\text { - Access to low-cost fresh food. } \\
\text { Example: "I think (for) a lot of them it would be a long way to go to get somewhere } \\
\text { as cheap as this, they would have to go to the city, Victoria Markets."(MSR2) }\end{array}$ \\
\hline & ㅍ & $\begin{array}{l}\text { - Delivery networks that cover all of the urban area. } \\
\text { Example: "we deliver all over Melbourne and we have what we call food hosts, } \\
\text { someone just donates their veranda. [...] we have } 75 \text { houses around Melbourne." } \\
\text { (MFH1) } \\
\text { - Second grade produce boxes available at cheaper prices. } \\
\text { Example: "We have a whole range of second produce, which the farmer sends } \\
\text { directly, so it is almost half the price and double the value." (BFH4) }\end{array}$ \\
\hline 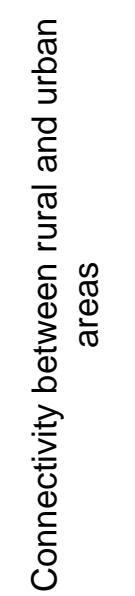 & 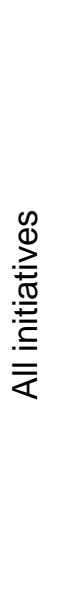 & $\begin{array}{l}\text { - Appropriate economic returns to farmers for their work. } \\
\text { Example: "We don't play people off against each other like the supermarkets do, we } \\
\text { don't mock around trying to push prices down, we don't use our market power } \\
\text { negatively." (MFH1) } \\
\text { - Opportunity to visit farmers. } \\
\text { Example: "We also take our costumers out to the farms, on farm tours, so that they } \\
\text { can look the farmer in the eye and thank them for the hard work, ask them any hard } \\
\text { questions about their growing methods, and it gives the farmer the acknowledgment } \\
\text { that they really need." (BFH2) } \\
\text { - Information about growers. } \\
\text { Example: "So the co-ops order the food and it is very clear who the grower is or } \\
\text { from where it came from." (BSR1) }\end{array}$ \\
\hline
\end{tabular}

Type*: UA - urban agriculture promoters; BG - buyers' groups; SR - specialist retailers; FH - food hubs.

\subsubsection{Healthy food availability and improved access to food}


AFNs distribute a range of products which are compatible with the Australian Government's dietary guidelines (NHMRC, 2013). It is still necessary to analyze whether Australian AFNs are accessible in terms of both affordability and geographic location (Gerster-Bentaya, 2015). Considering affordability, higher prices are not the central reason preventing access to AFNs in Australia. The Melbourne specialist retailer was a market for low income earners offering the most affordable prices in the area. Specialist retailers and food hubs had prices that were accessible for the majority of the population. A food hub box for two people costs around 40 Australian dollars and is affordable for people with an average income ${ }^{2}$. There might, however, be other reasons why consumers are not buying from food hubs (see section 4.3). In the case of the Brisbane specialist retailer, some products have higher prices but there was a focus on increasing the efficiency of operations to reduce costs, such as having a more accessible price for olive oil:

"We decided that we would just take 1000 litters IBC, which is a full cube of olive oil no packaging or anything, and that will help him (the producer) to get the cost down. So, a lot of that stuff we can talk to our customers about bringing back their packaging so we can refill it to work in the cost saving, so we are working on things like that." (BSR3)

The assumption that AFNs should reduce their prices to become more affordable is problematic for the Brisbane specialist retailer and the food hubs. Their prices were set to be economically, environmentally and socially sustainable. Alternatively, governments could adopt policy solutions to increase people's access to AFNs' produce. Examples of such measures include the adoption of welfare instruments to increase the purchasing power of low-income earners, and the provision of economic incentives to AFNs which allow them to have more competitive prices for their products (Hodgins and Fraser, 2017).

Buyers' groups have the potential to make healthy food more accessible to people on low incomes. All interviewees from buyers' groups stated that their organic food was available for prices lower than other outlets. The main strategies used to achieve lower

\footnotetext{
2 The average weekly income in 2016 in the Melbourne Metropolitan Region was of 673 per person and 1,542 per household in 2016, while in Brisbane City was of 770 per person and 1,746 per household (ABS, 2016).
} 
prices were: bulk purchasing; direct connections with farmers; and, the use of volunteer labor. Volunteering in buyers' groups consisted mostly of administrative work that could be conducted remotely. One of the groups also had a monthly commitment of three hours for volunteers to pack members' groceries. This model has the potential to be replicated in areas with low access to fresh food. The opportunity to increase access to fresh food using buyers' groups was also recognized by researchers in Italy and Spain (Fonte, 2013; Moragues-Faus, 2017; Pellicer-Sifres et al., 2017).

The urban agriculture initiatives analyzed were not focused solely on selling food, making a discussion of price less significant. What urban agriculture initiatives require in the Australian context is access to land and the inputs needed for food production which can be impaired by financial limitations. One of the initiatives from Melbourne and another from Brisbane had access to land through concessions provided by local councils. The second urban agriculture initiative from Melbourne worked with private landowners interested in having a garden and charged them only for materials. All the designing and building of their garden was based on volunteer work provided by the initiative.

Geographical accessibility varied according to the kind of AFNs. Food hubs had a system of pickup points distributed across urban areas and geographical access was not a limiting factor. In the case of the specialist retailers, the initiative from Melbourne located its markets in areas where residents had sensitive economic situations. The Brisbane specialist retailer had three selling points and supported buyers' groups to increase their range. The geographical accessibility of both urban agriculture and buyers' groups was dependent on their ability to have local presence in the suburbs.

The establishment of new AFNs can contribute to increasing access to healthy food by communities, but there are a number of factors that limit the access of certain groups to the AFNs model, especially low-income earners. The existence of social capital was a factor that emerged as crucial for the establishment of AFNs. Interviewees were able to create buyers' groups because they were already part of the AFNs' culture and had the right connections. A member from the Brisbane buyers' group reported that the establishment of procedures and structures for launching the initiative was an extensive task and was aided by external support from other AFNs: 
"We broke everyone into teams, each new team had a support person, from either another AFN or one person with previous experience, to help them in that early phase of establishing the habit, how the team would operate, how their responsibilities would operate, so there was a lot of documenting of processes around finance and stock." (BBG1)

Urban agriculture is another example of AFNs which can enhance access to fresh food by food insecure communities, however, they require good social networks like buyers' groups. An urban agriculture facilitator from Melbourne explained how urban gardens are only feasible for communities that have access to land, know the process for permit acquisition, and are familiar with food growing techniques. Opitz et al. (2016) also found that even when resources were available for urban agriculture initiatives it required effective organization from groups in order to access them.

The establishment of AFNs can be a great opportunity for local governments to increase fresh food access to vulnerable communities, however, there is still a need for building social capital for their development. The provision of support structures (e.g. networks with farmers, physical space for operation, basic materials) and dissemination of information are strategies that can be adopted by local governments in order to enable communities to create their own AFNs. It does not mean, however, that implementing policies to create AFNs in local communities will remove all individual limitations. The reliance on volunteer work, for instance, is a remaining limitation of the AFNs model which will be discussed further in section 4.3. What is important to emphasize here is that local governments should enhance efforts to expand and support AFNs - efforts that could in turn enhance food security of Australian UFS.

\subsubsection{Connectivity between rural and urban areas: The increase of rural debates into the urban space}

To have a more sustainable and resilient UFS the connection between rural and urban areas needs to be re-shaped. A different set of conditions needs to be created for farmers, especially those operating on a small scale, to reduce the number of farmers exiting the industry and make agriculture more attractive to young people (ABS, 2012). 
All the interviewees felt that farmers are being overburdened and AFNs are committed to cooperating with farmers in order to improve their financial security. All the food hubs and buyers' groups, and the Brisbane specialist retailer, indicated that they were committed to ensuring a fair payment to food producers. A manager from the Brisbane food hub explained the pricing system:

"I think around seventy percent of our farmers are happy with the flat price and the other thirty percent want to just go with the market, so they won't name a price until their produce comes in. Our dairy farm got a flat price. He earns three to four times more than any other dairy farmer." (BFH1)

Members from the Brisbane specialist retailer explained that the prices are based on an honest conversation, with agreements being grounded in mutual help and the assurance of a steady flow of income to the farmer. These AFNs are often approached by farmers who want to find outlets for their products where they feel more valued. The way that AFNs improve payments to farmers is by having a business model that: is notfor-profit; provides a shorter route between farmers and consumers; and, does not treat food as a commodity for financial speculation. This fairer relationship with farmers was also mentioned by other studies with buyers' groups, community supported agriculture and food hubs (Balázs et al., 2016; Fonte, 2013; Lutz and Schachinger, 2013).

Apart from better valuing farmers' work, AFNs also sought to ensure that a strong connection between farmers and urban consumers was being developed. Information about growers was provided by buyers' groups, food hubs, and specialist retailers to consumers. Stories about the farmers were shared in weekly newsletters which described when produce was in season and promoted events with farmers. Knowing these stories seems to help consumers to understand the reality of food production and its associated challenges. Farm tours are another example of events regularly organized to create connections. Even if not all the consumers engaged, AFNs in this study considered that these activities helped farmers to create a sense of belonging and appreciation.

\subsection{Environmental outcomes}


A summary of how AFNs contributed to achieving environmental outcomes is presented in Table 5. Urban agriculture had distinct contributions whereas other AFNs types presented similar benefits. All kinds of AFNs contributed to the reduction of food loss and waste. Considering environmental protection, the biggest opportunities presented by AFNs were the growth of food in urban and peri-urban areas with resource efficient techniques, and the adoption of agroecology farming methods.

Table 5: Links between AFNs and environmental outcomes of sustainable and resilient UFS. 


\begin{tabular}{|c|c|c|}
\hline 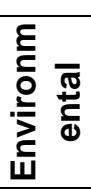 & 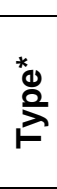 & Contributions \\
\hline \multirow{2}{*}{ 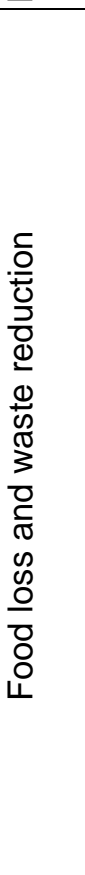 } & 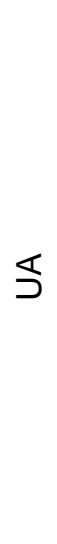 & $\begin{array}{l}\text { - Waste reduction of perishable foods. } \\
\text { Example: "There is always a big demand for sharing herbs in a communal bed and avoid } \\
\text { that horrible plastic wrapping or paying five dollars to get a tiny little bunch of basil." } \\
\text { (MUA1) } \\
\text { - Use of composting as final destination. } \\
\text { Example: "We do make a lot of compost and there are organic procedures for that as } \\
\text { well." (BUA1) } \\
\text { - Promotion of food swaps. } \\
\text { Example: "One of the tips is get to know your local food swap, [...] once you've got a fruit } \\
\text { tree [...] you are going to have excess." (MUA3) }\end{array}$ \\
\hline & $\begin{array}{l}\frac{I}{\square} \\
\frac{\sigma}{\sigma} \\
\frac{\sigma}{\sigma} \\
\widetilde{r} \\
\omega \\
0 \\
0\end{array}$ & $\begin{array}{l}\text { - No aesthetic standards for food. } \\
\text { Example: "We don't require cosmetic standards for our fruit and vegetables." (BFH1) } \\
\text { - No waste during retail. } \\
\text { Example: "If there is anything left, we try to sell it cheap in the end, basically we try to } \\
\text { have no waste, nothing leftover is the aim of every market." (MSR2) }\end{array}$ \\
\hline \multirow{2}{*}{ 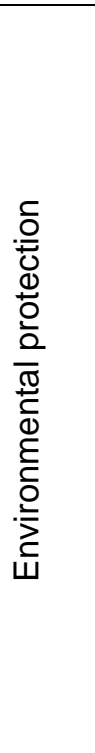 } & 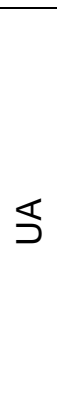 & $\begin{array}{l}\text { - Use of resource efficient food production such as wicking beds. } \\
\text { Example: "Wicking beds are really handy, even if it is like } 42 \text { degrees Celsius for a few } \\
\text { days, as long as their reservoir is full of water, you only have to top once every other } \\
\text { couple of weeks. You will find that it is lower maintenance than a standard garden bed." } \\
\text { (MUA3) } \\
\text { - Reduction of food miles. } \\
\text { Example: "Things that are highly perishable, leafy greens and herbs, you should produce } \\
\text { as close as possible to where you live." (BUA1) }\end{array}$ \\
\hline & $\begin{array}{l}\frac{T}{\square} \\
\square \\
\frac{\sigma}{\sigma} \\
\widetilde{r} \\
\tilde{\sigma} \\
0 \\
0 \\
\square\end{array}$ & $\begin{array}{l}\text { - Reduction of the use of packaging, especially plastic packs. } \\
\text { Example: "There is no package in the boxes." (MBG1) } \\
\text { - Support to agroecology farming and organics. } \\
\text { Example: "so we don't stock any conventional produce, we keep them in the loop } \\
\text { (conventional farmers) and put them in touch with other farmers who are doing really } \\
\text { good organic farming and can help them in their transition to natural farming." (BFH2) }\end{array}$ \\
\hline
\end{tabular}

Types*: UA - urban agriculture promoters; BG - buyers' groups; SR - specialist retailers; FH - food hubs.

\subsubsection{Food loss and waste reduction}

AFNs can reduce food loss and waste at all stages of the UFS. With regards to food production, members of urban agriculture initiatives advocate that growing 
perishable food in urban areas reduces waste. This was complemented by AFNs adoption of no aesthetic standards for their products. Supermarket chains adopt restrictive aesthetic standards for food which results in waste of perfectly good products during harvest simply because it looks odd (Murdoch and Miele, 2004).

In terms of distribution, specialist retailers reported no or minimal waste. In the case of food hubs and buyers' group, waste was avoided by the use of pre-ordering and e-commerce. This meant that they did not have large stocks or food displays. In addition, food hubs and buyers' groups are flexible regarding product availability (always observing seasonality), which created a more natural relationship with food procurement. Leftovers of bulk orders were minimal and purchased by members. In the case of food hubs, leftover produce was either sold as second grade for cheaper prices, donated to charity, or made into compost. All these initiatives tried to reduce packaging to a minimum and avoid the use of plastic.

At the consumption stage, AFNs studied made efforts to reduce food wastage, but their effectiveness was not clear. Urban agriculture initiatives supported food swaps where people exchanged excess produce from their own gardens. Urban agriculture initiatives, food hubs, and buyers' group provided workshops on techniques for preserving foods. Household food wastage was a clear concern of AFNs but some aspects suggested that they might not be having a significant impact on it. Ready-made boxes, for example, often meant that not all the produce was used. Interviewees who purchased from food hubs mentioned that sometimes products were wasted:

"The challenge is eating it before it goes bad and eating stuff that I wouldn't normally buy, and I don't know how to cook. Or I wouldn't normally buy because I don't actually like that much, so I'm less interested in eating that particular fruit or vegetable." (BFH5)

The above example highlights how intrinsic individual characteristics also play a role in the achievement of environmental outcomes sought by AFNs. These may present themselves as a barrier to expanding their environmental outcomes because it requires a considerable degree of flexibility on behalf of consumers who have to relax their food tastes and choices, be committed to supporting initiatives beyond their personal gains, or have a strong environmental ethos (Balazs et al. 2016; Moragues-Faus, 2017). 
Nevertheless, findings do not indicate that AFNs are increasing consumers' food waste. In fact, increasing the knowledge on food management and preservation is a strategy that has been adopted by AFNs to reduce households' food waste (Gallar Hernández et al., 2019).

AFNs studied also had a positive impact on the food disposal stage. Members of the two food hubs interviewed reported that compost was used as a final destination. Urban agriculture initiatives had composting facilities which could be used by anyone in the local community. Household food waste represents about five million tones in Australia and most of it goes to landfills (Pickin et al., 2018). Increased access to composting facilities in UFS has the potential to reduce the environmental impacts and GHG emissions associated with food waste (Adhikari et al., 2010; Vázquez and Soto, 2017), thereby, improving sustainability and resilience outcomes.

\subsubsection{Environmental protection and climate change mitigation and adaptation}

UFS are responsible for a number of environmental impacts that compromise ecosystem services and contribute to GHG emissions (Morgan and Sonnino, 2010). UFS should decouple from fossil fuels and change consumption patterns to mitigate climate change (James and Friel, 2015). In addition, food production techniques need to maintain ecosystem services and contribute to biodiversity to foster climate change adaptation (Toth et al., 2016). Many strategies adopted by AFNs serve the two-fold purposes of climate change mitigation and adaptation.

The first strategy present in AFNs is the growth of perishable food in urban and peri-urban areas using resource efficient techniques. This practice not only helps to reduce emissions created by food transport, but also supports adaptation by both diversifying land uses in the urban environment and UFS food sources. Unlike rural areas, the price or availability of resources such as land, water, and labor, can be prohibitive for growing food in the urban space. This requires initiatives to design efficient systems which are better prepared to deal with resource constraints. For example, some urban agriculture initiatives use a system of wicking beds that requires small areas, retains stormwater, is drought resistant, and is not labor intensive (Richards et al., 2017). 
Interviewees from urban agriculture initiatives believed that wicking beds were a great solution for growing leafy greens, herbs and non-invasive root vegetables in urban environments, and create food autonomy:

"We have interaction with some people who grow food on a scale that I think probably, even today, you couldn't convince every council that is possible, that someone could be growing pretty much all of their diet in their backyard." (MUA1)

The second main practice adopted by AFNs that can contribute to climate change mitigation and adaptation is the use of, and support for, agroecology farming systems. Agroecological farming, in all its variety and complexity, is usually practiced on smaller scales using a diversity of crops which tries to mimic the natural environment (Wezel et al., 2009). The use of farming techniques that are independent of petroleum derived pesticides, herbicides and fertilizers facilitate their de-coupling from fossil fuels (Altieri, 2002). Regenerative agriculture was the agroecology technique most frequently mentioned by AFNs members and classified by an interviewee as a climate change adaptation strategy. Regenerative agriculture is a technique that focuses on increasing soil quality by eliminating tillage and events of bare soil while fostering biodiversity of plants and animals (LaCanne and Lundgren, 2018).

Agroecological farming techniques have the potential of increasing carbon sequestration, and sustaining biodiversity and ecosystems services - aspects that are crucial for climate change mitigation and adaptation (Altieri et al., 2015). It should be emphasized, however, that this farming system is unlikely to suit all UFS. Agroecological farming is characterized by a diversity of products and often operated by small-scale farmers whose trade practices are at odds with wholesale markets which are based on large volumes, fixed contracts, and operate independently of the seasonality of supply (IPES-Food, 2016). Agroecological farming has the potential to feed UFS in a future of climate crisis and resource-scarce (Willett et al., 2019), but this requires compatible food supply models. AFNs have adapted their business models to better engage with agroecological farmers. These include the adoption of a flexible demand for products, the observance of seasonality, embracing food diversity, and using local varieties of food. 
These characteristics, together with the adequate economic compensation for agroecological products, is what makes viable the engagement of AFNs with agroecological farmers. Even if initiatives work to reduce food miles, lower food waste, and use sustainable packaging, the successful engagement with agroecological farming is the most crucial aspect that could allow AFNs to be a key player in environmental protection and climate change adaptation beyond the urban boundary.

\subsection{Alternative food networks limitations}

There were three principal limiting factors to expanding AFNs presence in the case studies: access to land, broader public engagement, and reliance on volunteer labor. First, interviewees pointed to how reduced access to land in urban areas had directly affected urban agriculture initiatives. A stagnation or reduction of food production in urban and peri-urban areas, however, can also impact the local food supply from other kinds of AFNs. Land access in urban and peri-urban areas is also a challenge for urban agriculture development in the Global North (Cerrada-Serra et al., 2018). In the Australian context the problem is often bureaucracies that prevent access to existing vacant lots rather than a scarcity of free land. Thornton (2017) also reported obstacles in Canberra and Sydney to access state and local government land for community gardens and attributed these to city officials not engaging in cooperative relationships, along with statutory barriers such as spatial planning and land tenure regulations. An urban agriculture facilitator from Melbourne described how the administrative procedures to have access to public land can be a challenge:

"It took six years of negotiation with the Council, as you can imagine if you got a community that it is really passionate, after about six years you are going to lose a lot of people that were just like 'this is way too hard"' (MUA1)

Soil contamination in urban areas can also prevent access to land. Interviewees mentioned that there are ways of dealing with contaminated soil, however, the risk of future liability issues can prevent the allocation of council land for urban agriculture.

Second, public engagement with the different models of AFNs can also be a challenge. People are habituated to the convenience and variety attached with shopping 
in supermarkets and it can be hard to see the value of using AFNs. A result of what McMichael (2009) describes as 'the food from nowhere regime', where there is a lack of visibility for consumers of the social injustices, environmental impacts, and health risks related to many supply chains. Members of the food hubs suggested that more transparency in food systems on these issues would favor AFNs. Other case studies reported that a lack of awareness meant that initiatives needed to spend time educating the community on AFNs' value (Doernberg et al., 2016; Freidberg and Goldstein, 2011; Miralles et al., 2017). A manager from the Brisbane food hub mentioned that when people value their model only by its convenience AFNs will much likely lose to supermarkets.

Finally, the reliance of AFNs on volunteer work can also be a limitation. Balazs et al. (2016) stated that AFNs models requiring a significant degree of unpaid work usually end up not being self-sustainable. Members of buyers' groups indeed agreed that volunteer work made their model not a good fit for everyone. One interviewee from the Brisbane buyers' group mentioned occasions where new members were surprised that the initiative was an exchange system that required volunteer work, rather than a membership service. This study also confirmed that volunteers usually needed to reconcile AFNs' tasks with their jobs, family and social commitments, limiting the energy and time they could dedicate to the initiatives.

\section{Conclusion}

This paper focused on the contributions of AFNs to delivering sustainable and resilient outcomes for the UFS in the city of Brisbane and four local governments in the Melbourne metropolitan region. Overall, initiatives started with the goal of creating a more localized food supply but ended up addressing many UFS related issues. In particular, the AFNs studied have increased access to fresh food in areas that previously had few food outlet options, and developed operational models that improved the affordability of organic food. In addition, food waste was reduced by using resource efficient strategies such as smaller supply chains with no aesthetic standards, and generic orders (e.g. vegetable and fruit boxes) that match products availability. The AFNs' use of, and support 
for, agroecology techniques have also enabled a food production system that, to some extent, is helping to protect the environment.

In terms of challenges, the potential of AFNs to improve people's access to healthy food seemed to have lacked adequate support by local governments. For example, buyers' groups could be expanded with the support of local authorities to increase people's access to fresh food in regions experiencing food insecurity. Additionally, AFNs improved the financial security of farmers and producers by providing a fairer income, however, a higher participation of farmers in AFNs structures could further increase this contribution. AFNs are working to reduce UFS food waste and actions specifically targeting the consumption stage could help to achieve even better results.

Notably, an expansion of the different AFNs' models could increase and intensify the many benefits they are already generating. To scale up, AFNs need greater visibility from both urban and rural actors. The creation of support structures by local governments could significantly help the establishment of new and strengthen existing AFNs. These could be regional platforms, umbrella organizations or knowledge hubs which could act as network bridging organizations (Dedeurwaerdere et al., 2017). Governments could also secure and increase food production in urban and peri-urban areas to create a more balanced distribution of sources and easier access to perishable foods. Increasing urban agricultural areas and their composting facilities could also improve nutrient recovery and reduce food waste. Finally, governments could facilitate the provision of financial support to encourage food to be purchased from AFNs, therefore fostering initiatives and increasing fresh food access.

There are many pathways to sustainable and resilient UFS, and different methods of food provisioning are already growing around the world. Questions remain, however, as to what options will be seen as desirable, and what will be supported by governments and communities. AFNs are creating more sustainable and resilient configurations in Australian UFS and should be considered as a constructive pathway for change. Other models of food provision could learn from AFNs' achievements, but this will only be possible if AFNs are more visible. Further research could improve the understanding of how AFNs in Australia are viewed by other UFS actors (e.g. communities, retailers, restaurants) and governments. In particular, knowing the level of community interest in 
AFNs' activities is important because the creation of new initiatives, and the expansion of current ones, depends on community support. A closer analysis of how local policies support the emergence and continuity of AFNs is also necessary.

\section{References}

Adhikari, B.K., Trémier, A., Martinez, J., Barrington, S., 2010. Home and community composting for on-site treatment of urban organic waste: perspective for Europe and Canada. Waste Management \& Research. 28, 1039-1053. https://doi.org/10.1177/0734242X10373801

Altieri, M.A., 2002. Agroecology: the science of natural resource management for poor farmers in marginal environments. Agriculture Ecosystems \& Environment. 93, 1-24.

https://doi.org/10.1016/S0167-8809(02)00085-3

Altieri, M.A., Nicholls, C.I., Henao, A. et al., 2015. Agroecology and the design of climate change-resilient farming systems. Agrononomy for Sustainable Development 35, 869-890. https://doi.org/10.1007/s13593-015-0285-2

Anderson, M.D., 2015. The role of knowledge in building food security resilience across food system domains. Journal of Environmental Studies and Sciences 5, 543-559.

https://doi.org/10.1007/s13412-015-0311-3

Australian Bureau of Statistics, 2012. Australian Social Trends, Dec 2012. Retrieved from. http://www.abs.gov.au/AUSSTATS/abs@.nsf/Lookup/4102.0Main+Features10Dec+2012\#FAR MERS\%20IN (accessed in 19 February 2019).

Australian Bureau of Statistics, 2016. 2016 Census QucikStats, Dec 2018. Retrived from http://quickstats.censusdata.abs.gov.au/census_services/getproduct/census/2016/quickstat/UC L301001?opendocument (accessed in 13 March 2019).

Balázs, B., Pataki, G., Lazányi, O., 2016. Prospects for the future: Community supported agriculture in Hungary. Futures 83, 100-111. https://doi.org/10.1016/..futures.2016.03.005

Billen, G., Garnier, J., Thieu, V., Silvestre, M., Barles, S., Chatzimpiros, P., 2012. Localising the nitrogen imprint of the Paris food supply: the potential of organic farming and changes in human diet. Biogeosciences 9, 607-616. https://doi.org/10.5194/bg-9-607-2012

Blay-Palmer, A., Renting, H., Dubbeling, M., 2015. Understanding the city region food system (CRFS): Planning for a more food secure and resilient city.

Bristol City Council, 2013. A good food plan for Bristol.

Burton, P., Lyons, K., Richards, C., Amati, M., Rose, N., Desfours, L., Pires, V., Barclay, R., 2013. Urban food security, urban resilience and climate change. National Climate Change Adaptation Research Facility, Gold Coast. 
Byrne, D., 2016. What is content analysis?, in: Data Analysis and Interpretation. SAGE Publications, Inc, London.

Calori, A., Dansero, E., Pettenati, G., Toldo, A., 2017. Urban food planning in Italian cities: a comparative analysis of the cases of Milan and Turin. Agroecology and Sustainable Food Systems. 41, 1026-1046. https://doi.org/10.1080/21683565.2017.1340918

Carey, J., 2013. Urban and Community Food Strategies. The Case of Bristol. International Planning Studies. 18, 111-128. https://doi.org/10.1080/13563475.2013.750938

Chiffoleau, Y., Sarah, M.-A., Canard, A., 2016. From Short Food Supply Chains to Sustainable Agriculture in Urban Food Systems: Food Democracy as a Vector of Transition. Agriculture 6, 57. https://doi.org/10.3390/agriculture6040057

City of Darebin, 2014. Urban food production strategy 2014 - 2018.

City of Malmo, 2010. Policy for sustainable development and food.

City of Milan, 2015. Milan Urban Food Policy Pact.

Cleveland, D.A., Carruth, A., Mazaroli, D.N., 2015. Operationalizing local food: goals, actions, and indicators for alternative food systems. Agriculture and Human Values 32, 281-297. https://doi.org/10.1007/s10460-014-9556-9

Cretella, A., Buenger, M.S., 2016. Food as creative city politics in the city of Rotterdam. Cities 51, 1-10. https://doi.org/10.1016/j.cities.2015.12.001

Custot, J., Dubbeling, M., Getz-Escudero, A., Padgham, J., Tuts, R., Wabbes, S., 2012.

Resilient Food Systems for Resilient Cities, in: Local Sustainability.

Dedeurwaerdere, T. et al., 2017. The Governance Features of Social Enterprise and Social Network Activities of Collective Food Buying Groups. Ecological Economics. 140, 123-135. https://doi.org/10.1016/j.ecolecon.2017.04.018

Desmarais, A.A., Wittman, H., 2014. Farmers, foodies and First Nations: getting to food sovereignty in Canada. The Journal of Peasant Studies. 41, 1153-1173. https://doi.org/10.1080/03066150.2013.876623

Dixon, J., Richards, C., 2016. On food security and alternative food networks: understanding and performing food security in the context of urban bias. Agriculture and Human Values 33, 191-202. https://doi.org/10.1007/s10460-015-9630-y

Doernberg, A., Zasada, I., Bruszewska, K., Skoczowski, B., Piorr, A., 2016. Potentials and Limitations of Regional Organic Food Supply: A Qualitative Analysis of Two Food Chain Types in the Berlin Metropolitan Region. Sustainability 8, 1125. https://doi.org/10.3390/su8111125

Donovan, J., Larsen, K., McWhinnie, J.A., 2011. Food-sensitive planning and urban design.

Folke, C., 2016. Resilience. Oxford Research Encyclopedia of Environmental Science. https://doi.org/10.1093/acrefore/9780199389414.013.8 
Fonte, M., 2013. Food consumption as social practice: Solidarity Purchasing Groups in Rome, Italy. Journal of Rural Studies. 32, 230-239. https://doi.org/10.1016/j.jrurstud.2013.07.003

Food Bank, 2018. Food Bank Hunger Report 2018.

Forssell, S., Lankoski, L., 2015. The sustainability promise of alternative food networks: an examination through "alternative" characteristics. Agriculture and Human Values 32, 63-75. https://doi.org/10.1007/s10460-014-9516-4

Forssell, S., Lankoski, L., 2016. Navigating the tensions and agreements in alternative food and sustainability: a convention theoretical perspective on alternative food retail. Agriculture and Human Values. https://doi.org/10.1007/s10460-016-9741-0

Freidberg, S., Goldstein, L., 2011. Alternative food in the global south: Reflections on a direct marketing initiative in Kenya. Journal of Rural Studies. 27, 24-34.

https://doi.org/10.1016/j.jrurstud.2010.07.003

Gallar Hernández, D., Saracho-Domínguez, H., Rivera-Ferré, M. G., \& Vara-Sánchez, I. (2019). Eating Well with Organic Food: Everyday (Non-Monetary) Strategies for a Change in Food Paradigms: Findings from Andalusia, Spain. Sustainability, 11(4), 1003.

Galt, R.E., 2013. The moral economy is a double-edged sword: Explaining farmers' earnings and self-exploitation in community-supported agriculture. Economic Geography. 89, 341-365.

Garnett, T., 2014. Three perspectives on sustainable food security: efficiency, demand restraint, food system transformation. What role for life cycle assessment? Journal of Cleaner Production 73, 10-18. https://doi.org/10.1016/j.jclepro.2013.07.045

Gerster-Bentaya, M., 2015. Urban agriculture's contributions to urban food security and nutrition, in: Cities and Agriculture: Developing Resilient Urban Food Systems.

Giddings, B., Hopwood, B., O'Brien, G., 2002. Environment, economy and society: fitting them together into sustainable development. Sustainable Development. 10, 187-196.

https://doi.org/10.1002/sd.199

Guitart, D.A., Byrne, J.A., Pickering, C.M., 2015. Greener growing: assessing the influence of gardening practices on the ecological viability of community gardens in South East Queensland, Australia. Journal of Environmental Planning and Management. 58, 189-212.

https://doi.org/10.1080/09640568.2013.850404

Hamm, M.W., Baron, M., 1999. Developing and Integrated Sustainable Urban Food System: The case of New Jersey, United States, in: For Hunger-Proof Cities: Sustainable Urban Food Systems. pp. 54-59.

Hanson, L.L., Schrader, D., 2014. Creating New Urban Spaces of Sustainability and Governmentality: An Assessment of the Development of a Food and Urban Agriculture Strategy for Edmonton, Canada, in: Holt, W.G. (Ed.), Research in Urban Sociology. Emerald Group Publishing Limited, pp. 191-214. 
Hodgins, K. J., \& Fraser, E. D. (2018). " We are a business, not a social service agency." Barriers to widening access for low-income shoppers in alternative food market spaces. Agriculture and human values, 35(1), 149-162.

Hughes, L., Steffen, W., Rice, M., Pearce, A., 2015. Feeding a hungry nation: climate change, food and farming in Australia.

IPES-Food, 2016. From uniformity to diversity: a paradigm shift from industrial agriculture to diversified agroecological systems. International Panel of Experts on Sustainable Food systems.

James, S.W., Friel, S., 2015. An integrated approach to identifying and characterising resilient urban food systems to promote population health in a changing climate. Public Health Nutrition. 18, 2498-2508. https://doi.org/10.1017/S1368980015000610

Jennings, S., Cottee, J., Curtis, T., Miller, S., 2015. Food in an urbanised world: the role of city region food systems in resilience and sustainable development.

Kopczynska, E., 2017. Economies of Acquaintances: Social Relations during Shopping at Food Markets and in Consumers' Food Cooperatives. East European Politics And Societies 31, 637658.

LaCanne, C.E., Lundgren, J.G., 2018. Regenerative agriculture: merging farming and natural resource conservation profitably. PeerJ 6, e4428. https://doi.org/10.7717/peerj.4428

Lawrence, G., Richards, C., Lyons, K., 2013. Food security in Australia in an era of neoliberalism, productivism and climate change. Journal of Rural Studies. 29, 30-39. https://doi.org/10.1016/j.jrurstud.2011.12.005

Le Velly, R., Dufeu, I., 2016. Alternative food networks as "market agencements": Exploring their multiple hybridities. Journal of Rural Studies 43, 173-182.

https://doi.org/10.1016/j.jrurstud.2015.11.015

Longo, P., 2016. Food Justice and Sustainability: A New Revolution. Agriculture and Agricultural Science Procedia 8, 31-36. https://doi.org/10.1016/j.aaspro.2016.02.005

Lutz, J., Schachinger, J., 2013. Do Local Food Networks Foster Socio-Ecological Transitions towards Food Sovereignty? Learning from Real Place Experiences. Sustainability 5, 47784796. https://doi.org/10.3390/su5114778

McMichael, P., 2009. A food regime genealogy. Journal of Peasant Studies. 36, 139-169. https://doi.org/10.1080/03066150902820354

Melbourne Council, 2012. Food city: City Of Melbourne food policy. City of Melbourne, Melbourne.

Moragues-Faus, A., 2017. Emancipatory or Neoliberal Food Politics? Exploring the "Politics of Collectivity" of Buying Groups in the Search for Egalitarian Food Democracies: Emancipatory or Neoliberal Food Politics? Antipode 49, 455-476. https://doi.org/10.1111/anti.12274

Moragues-Faus, A., Marceau, A., Andrews, T., 2016. Making the case and measuring progress: Towards a systems approach to healthy and sustainable food. 
Moragues-Faus, A., Morgan, K., 2015. Reframing the foodscape: the emergent world of urban food policy. Environment and Planning A 47, 1558-1573.

https://doi.org/10.1177/0308518X15595754

Moreland City Council, 2017. Moreland Food System Strategy 2017-2020.

Morgan, K., 2015. Nourishing the city: The rise of the urban food question in the Global North. Urban Studies. 52, 1379-1394. https://doi.org/10.1177/0042098014534902

Morgan, K., Sonnino, R., 2010. The urban foodscape: world cities and the new food equation. Cambridge Journal of Regions, Economy and Society. 3, 209-224.

https://doi.org/10.1093/cjres/rsq007

Murdoch, J., Miele, M., 2004. A new aesthetic of food? Relational reflexivity in the "alternative" food movement, in: Qualities of Food. Manchester University Press, Manchester and New York, pp. 156-175.

NHMRC, 2013. Australian Dietary Guidelines.

Opitz, I., Specht, K., Berges, R., Siebert, R., Piorr, A., 2016. Toward Sustainability: Novelties, Areas of Learning and Innovation in Urban Agriculture. Sustainability 8, 356.

https://doi.org/10.3390/su8040356

Patton, M.Q., 2015. Qualitative Research \& Evaluation Methods, fourth edition. ed. SAGE Publications, Inc.

Pellicer-Sifres, V., Belda-Miquel, S., López-Fogués, A., Boni Aristizábal, A., 2017. Grassroots Social Innovation for Human Development: An Analysis of Alternative Food Networks in the City of Valencia (Spain). Journal of Human Development Capabilities. 18, 258-274.

https://doi.org/10.1080/19452829.2016.1270916

Pickin, J., Randell, P., Trinh, J., Grant, B., 2018. National Waste Report 2018126.

Pinna, S., 2017. Alternative farming and collective goals: Towards a powerful relationships for future food policies. Land Use Policy 61, 339-352.

https://doi.org/10.1016/j.landusepol.2016.11.034

Richards, P.J., Williams, N.S.G., Fletcher, T.D., Farrell, C., 2017. Can raingardens produce food and retain stormwater? Effects of substrates and stormwater application method on plant water use, stormwater retention and yield. Ecological Engineering 100, 165-174.

https://doi.org/10.1016/j.ecoleng.2016.12.013

Rockstrom, J. et al.,. 2009. "A safe operating space for humanity." Nature 461 (7263):472-475.

Rossi, A., 2017. Beyond Food Provisioning: The Transformative Potential of Grassroots Innovation around Food. Agriculture 7, 6. https://doi.org/10.3390/agriculture7010006

RUAF, 2013. Cityfood: Linking Cities on Urban Agriculture and Urban Food Systems. 
Saulters, M.M., Hendrickson, M.K., Chaddad, F., 2018. Fairness in alternative food networks: an exploration with midwestern social entrepreneurs. Agriculture and Human Values.

https://doi.org/10.1007/s10460-018-9852-x

Sonnino, R., 2017. The cultural dynamics of urban food governance. City Cult. Soc. https://doi.org/10.1016/j.ccs.2017.11.001

Sonnino, R., Spayde, J., 2014. The "new frontier"? Urban strategies for food security and sustainability, in: Sustainable Food Systems: Building a New Paradigm. Routledge, New York, NY.

Sonnino, R., Tegoni, C.L.S., De Cunto, A., 2018. The challenge of systemic food change: Insights from cities. Cities. https://doi.org/10.1016/j.cities.2018.08.008

Thornton, A., 2017. "The Lucky country"? A critical exploration of community gardens and citycommunity relations in Australian cities. Local Environment. 1-17.

https://doi.org/10.1080/13549839.2017.1317726

Toth, A., Rendall, S., Reitsma, F., 2016. Resilient food systems: a qualitative tool for measuring food resilience. Urban Ecosystems. 19, 19-43. https://doi.org/10.1007/s11252-015-0489-X

Vázquez, M.A., Soto, M., 2017. The efficiency of home composting programmes and compost quality. Waste Managment. 64, 39-50. https://doi.org/10.1016/..wasman.2017.03.022

Vieira, L.C., Serrao-Neumann, S., Howes, M., Mackey, B., 2018. Unpacking components of sustainable and resilient urban food systems. Journal of Cleaner Production 200, 318-330. https://doi.org/10.1016/j.jclepro.2018.07.283

Wezel, A., Bellon, S., Doré, T., Francis, C., Vallod, D., David, C., 2009. Agroecology as a science, a movement and a practice. A review. Agronomy for Sustainable Development 29, 503-515. https://doi.org/10.1051/agro/2009004

Willett, W. et al., 2019. Food in the Anthropocene: the EAT-Lancet Commission on healthy diets from sustainable food systems. The Lancet. https://doi.org/10.1016/S0140-

$\underline{6736(18) 31788-4}$

Wiskerke, J.S.C., 2015. Urban Food Systems, in: Cities and Agriculture: Developing Resilient Urban Food Systems. Routledge, New York, NY.

Yarra City Council, 2014. Urban Agriculture Strategy 2014-2018.

Yin, R.K., 2009. Case Study Research: Design and Methods, fourth edition. ed. SAGE Publications, Inc. 